Annals of Plant and Soil Research 22(4): 373-379 (2020)

https://doi.org/10.47815/apsr.2020.10007

\title{
Potentiality and irrigability assessment of Shiwalik hill soils of Himachal Pradesh
}

\section{SANJEEV K. CHAUDHARY*}

\author{
Department of Soil Science and Water Management, Dr. YS Parmar University of Horticulture and Forestry, \\ Solan, Himachal Pradesh, 173230
}

Received: July, 2020; Revised accepted: September, 2020

\begin{abstract}
The soils and lands developed under sub-humid sub-tropical climate of Shiwalik foot hills of Himachal Pradesh were evaluated for their productivity and potentiality under different land uses viz. agriculture, pastures and forest/tree crops and suitability for sustained irrigation. The actual productivity of these soils for agriculture was rated extremely poor to nil, poor and average comprising 80.4, 11.3 and $4.4 \%$ of total geographical area (TGA) of the watershed, respectively. The corresponding productivity for pastures was 12.0, 51.2 and $33 \%$ of TGA. The actual productivity of all these lands for forest/tree land use was found to be extremely poor to nil. The potential productivity for agriculture was in poor, average, good and excellent classes comprising 64.4, 10.5, 12.7 and $8.6 \%$ of TGA, respectively. Whereas, it was found to be average, good and excellent for pastures in 39.4, 48.2 and $8.6 \%$ of TGA, respectively. For forest/tree land use, the potential productivity was found to be extremely poor to nil for majority of the soils comprising 74\% of TGA. Other classesviz. poor and average covered only 14.7 and $7.5 \%$ of TGA, respectively. Thus, productivity of most of the soils could be increased to a greatextent by applying improvement measures to overcome the identified constraints as indicated by their potential productivity classes.Based on characteristics pertaining to soil, topography, drainage conditions and cost of land development these lands were classified into four irrigability sub-classes (3s, 4ts, 5ts and 6ts) according to the kind and degree of limitations for sustained use under irrigation. The respective classes covered 115.71, 105.2, 380.45 and 797.29 ha comprising 8.0, 7.2, 26.2 and 54.8\% of TGA, there being no class 1 or 2 irrigable land. Topography, shallow soil depth, coarse soil texture, high permeability and low available water capacity are the main limiting factors identified those may be manipulated suitably to increase production potential of these lands.
\end{abstract}

Key words: Land productivity, potentiality, land irrigability, land use, Shiwalik hills

\section{INTRODUCTION}

The state of Himachal Pradesh is predominantly a hilly area where majority (about $71 \%$ ) of the total population is dependent on agriculture and allied activities for livelihood. Pastures and forests/trees form integral components of such an agro- ecosystem. People have small land holdings (average size $<1$ ha) in scattered pockets and only a small proportion (about $40 \%$ ) of total geographical area of the state is suitable for arable farming. Land being a scarce natural resource, needs to be utilized in most appropriate way. For effective utilization of the same, it is important to evaluate the available lands for sustained production of crops, pasture biomass and forests/trees so that productivity from all land uses is enhanced.Further, more than $80 \%$ of cultivated area of Himachal Pradesh is rain fed. Rainfall distribution pattern in the state is skewed which is bimodal in nature i.e. major part of it (about $80 \%$ ) is received as summer rainfall from mid June to mid September during which the soil profile is subjected to eluviation, leaching and high run off rates due to heavy rainfall. Residual soil water is utilized in October/November. However, winters are left with very little rainfall. Consequently, the area faces soil water deficit during December to June when cultivation has to be supplemented by irrigation. The suitability of soils for sustained use under irrigation depends upon characteristics like available moisture holding capacity, effective rooting depth and intake characteristics. It is important to evaluate productivity of these lands for various land uses, their susceptibility to improvement and to ascertain suitability for irrigation. Such a study will enable most appropriate use of land and water, thereby helping in increasing productivity and production potential of soils in this hilly transect. Hence, the study was initiated for potentiality and irrigability assessment in hill soils of Mandhala watershed in Himachal Pradesh. 


\section{MATERIALS AND METHODS}

The study area (Mandhala watershed), a part of NW Himalayas, is located between $30^{\circ}$ $53^{\prime} 45^{\prime \prime}$ to $30^{\circ} 56^{\prime} 15^{\prime \prime} \mathrm{N}$ latitudes and $76^{\circ} 50^{\prime}$ to $76^{0} 54^{\prime} \mathrm{E}$ longitudes representing Shiwalik foot hills of Himachal Pradesh. The climate of the area is sub-humid sub-tropical monsoonic type with an average annual rainfall of about 1000 $\mathrm{mm}$. May and June are the hottest months while December and January are the coldest months of the year. Physiographic analysis of the study area based on visual interpretation of PAN and IRS-IC LISS III imagery and Survey of India (SOI) toposheet in conjunction with ground truth verification yielded 18 soil scape mapping units formulated on the basis of location, slope, elevation, land use as well as soil characteristics (Table 1). Surface features like slope, existing land use, erosion status and other morphological characters were recorded in the field. Representative soil samples collected from mapping units were analysed for various physico chemical properties using standard laboratory procedures (Jackson, 1973; Sarma et al., 1987).

Actual as well as potential productivity (potentiality) of these soils was quantitatively assessed for various land use options viz. agriculture, pastures and forest/trees following the soil appraisal system given by Riquier et al. (1970), one of the most widely used parametric methods of land evaluation because of its simplicity and suitability for small areas. The underlying principle in this system is that if favorable conditions extraneous to the soil are present (sound husbandry, good plant varieties, freedom from insect/pests etc.), the productivity theoretically possible, can be expressed by reference to the intrinsic soil characteristics (considered most relevant to studied soils) like moisture $(H)$, drainage $(D)$, effective depth $(P)$, texture or structure $(T)$, base saturation $(\mathrm{N})$, organic matter content $(\mathrm{O})$, cation exchange of clays $(A)$ and amount of mineral reserves (M). Ratings (0-100) for each of these factors were selected from tables I and II of Riquier's model. The factorized scores for each property were mutually multiplied and expressed as percentage to derive a final productivity index as below:

Productivity Index =

$$
(H / 100)^{\star}(\mathrm{D} / 100)^{\star}(\mathrm{P} / 100)^{*}(\mathrm{~T} / 100)^{*}(\mathrm{~N} / 100)^{\star}(\mathrm{O} / 100
$$
)$^{\star}(\mathrm{A} / 100)^{\star}(\mathrm{M} / 100)^{*} 100$
Productivity ratings i.e. extremely poor to nil, poor, average, good and excellent corresponding to productivity index score of 0-7, $8-19,20-34,35-64$ and $65-100 \%$ were worked out for each soil scape mapping unit for agriculture, pasture and forest/tree land use. In this order, these categories were designated as class 5, 4, 3, 2 and 1 in case of actual and class V, IV, III, II and I in case of potential productivity. Potential productivity was calculated after a careful consideration of all the possible improvement measures. An additional $10 \%$ was added in the value of index to account for any extraneous factors that may indirectly affect the productivity. Coefficient of improvement $(\mathrm{Cl})$ was determined from the ratio of potential productivity index $\left(P^{\prime}\right)$ to actual productivity index $(P)$.

The soil and land irrigability classification was done as per the procedure developed by US Bureau of Land Reclamation (Soil Survey Staff, 1951). There are six irrigability classes represented by Arabic number 1 through 6 . Soils are grouped into irrigability classes by matching the criteria established for each class irrespective of quality and quantity of water, land preparation costs and other non soil related factors. The most limiting property determines the irrigability class. The suitability of land for sustained use under irrigation on the other hand, also takes into account the drain ability of land, effect of irrigation water on salinity/ alkalinity status of soils and the cost of land development. Considering the specific limitations of soil (s), drainage (d) and topography (t), the sub-class level notations were suffixed to soil irrigability class. Maps pertaining to productivity and irrigability suitability were generated and interpreted at 1:12,500 scale using GIS system ARC/INFO (version 7.4).

\section{RESULTS AND DISCUSSION}

\section{Productivity and potentiality assessment}

The actual productivity for agriculture was found to be extremely poor to nil $(\mathrm{H} 11, \mathrm{H} 12$, $\mathrm{H} 13, \mathrm{H} 21, \mathrm{H} 22, \mathrm{H} 24, \mathrm{H} 25, \mathrm{P} 12, \mathrm{P} 22, \mathrm{P} 23, \mathrm{P} 24$, FP1 and FP2 units), poor (H23, P11 and P13 units) and average (P21 and FP3 units) (Table 2 ). These three classes comprised $80.4,11.3$ and $4.4 \%$ of TGA of the watershed, respectively (Fig. 1). As revealed by data (Table 2), the actual productivity for pastures was extremely poor to nil (P22, P23, P24, FP1 and FP2 units), 
poor $(\mathrm{H} 11, \mathrm{H} 21, \mathrm{H} 23, \mathrm{H} 24, \mathrm{P} 11, \mathrm{P} 12$ and $\mathrm{P} 13$ units) and average ( $\mathrm{H} 12, \mathrm{H} 13, \mathrm{H} 22, \mathrm{H} 25, \mathrm{P} 21$ and FP3 units) comprising 12.0, 51.2 and $33 \%$ of TGA of the watershed, respectively (Fig. 1). Actual productivity of all the units for forest/tree land use was found to be extremely poor to nil comprising $96.2 \%$ of TGA of the watershed (Fig. 1).A close scrutiny of data (Table 2) further reveals that potential productivity for agriculture varied from poor $(\mathrm{H} 11, \mathrm{H} 12, \mathrm{H} 13, \mathrm{H} 21, \mathrm{H} 22$, $\mathrm{H} 24, \mathrm{H} 25$ and P22 units), average (P12, P13 and FP1 units), good (H23, P23, P24 and FP2 units) to excellent (P11, P21 and FP3 units). These four categories covered 936.52, 152.84, 184.91 and 124.38 ha area (Fig. 2) comprising $64.4,10.5,12.7$ and $8.6 \%$ of TGA of the watershed, respectively (Figs. 1 \& 2). Potential productivity for pastures was found to be average ( $\mathrm{H} 11, \mathrm{H} 12$ and $\mathrm{H} 13$ units), good $(\mathrm{H} 21$, H22, H23, H24, H25, P12, P13, P22, P23, P24,
FP1 and FP2 units) and excellent (P11, P21 and FP3 units) as presented in table 2. These three classes covered 573.25, 701.03 and 124.37 ha area (Fig. 2) comprising $39.4,48.2$ and $8.6 \%$ of TGA of the watershed, respectively (Figs. $1 \& 2$ ). As evident from table 2, the productivity for forest/trees couldn't be improved in majority of the soils $(\mathrm{H} 11, \mathrm{H} 12, \mathrm{H} 13, \mathrm{H} 21, \mathrm{H} 22, \mathrm{H} 24, \mathrm{H} 25$, P12, P13, P22 and FP1 units) spread over 1076.04 ha (Fig. 2) comprising 74\% of TGA of the watershed (Figs. 1 \& 2). Other classes viz. poor (P11, P23, P24 and FP2 units) and average (H23, P21 and FP3 units) comprised only 14.7 and $7.5 \%$ of TGA of the watershed, respectively. The $\mathrm{Cl}$ varied from 1.56 to $10.01,1.33$ to 7.79 and 2.74 to 17.20 for agriculture, pasture and forest/tree land use in order, indicating P22 unit offered maximum scope for improvement for agriculture and pastures while P11 unit offered maximum improvement for forest/tree land use.

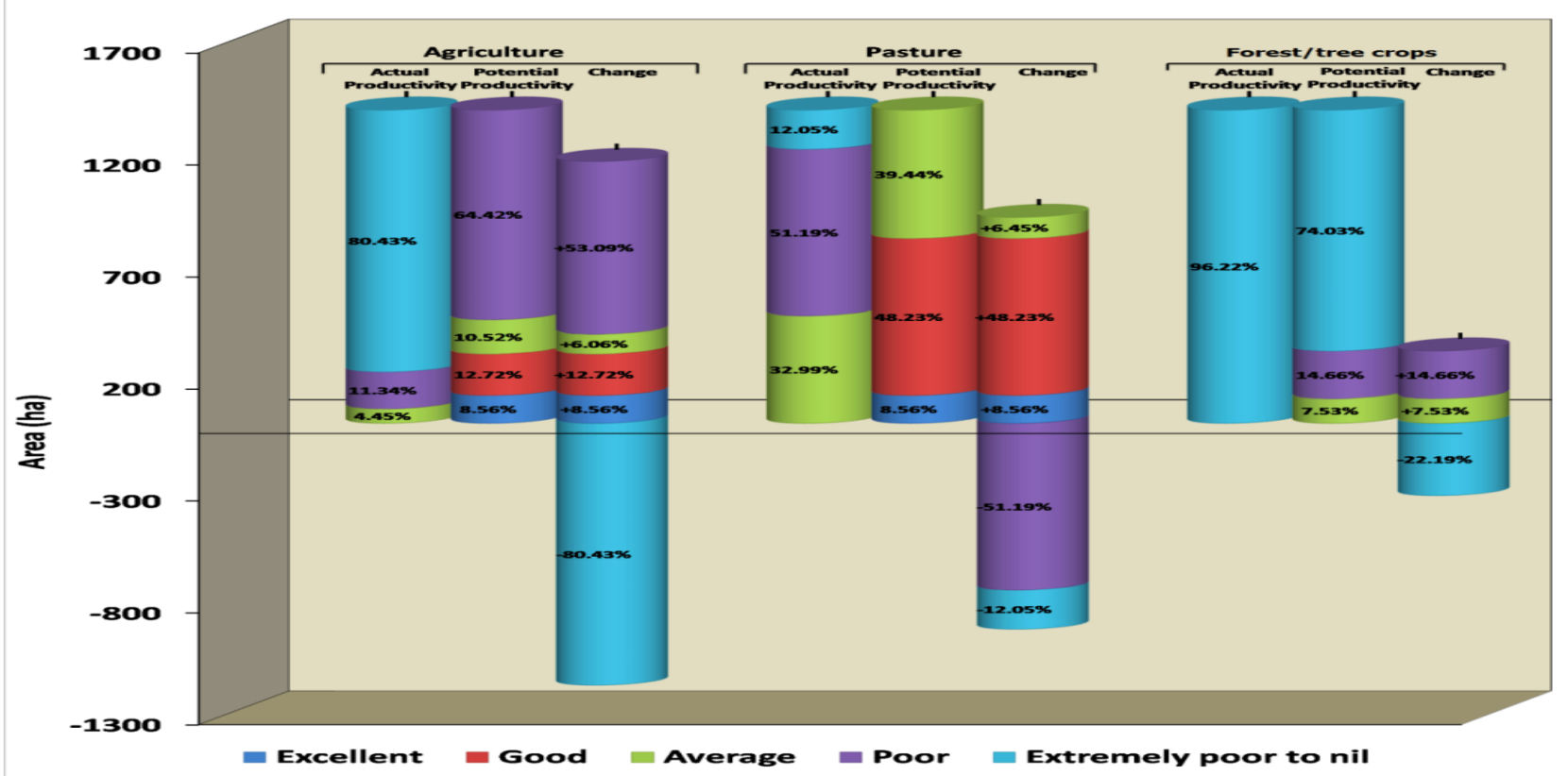

Fig. 1 :Actual versus potential productivity of different land uses in Mandhala watershed

The main factors limiting the actual productivity of these soils are shallow soil depth, coarse soil texture and low available water capacity. It can be seen (Fig.1) that no mapping unit qualified for the actual productivity class good or excellent owing to existing limitations. However, after adopting suitable improvement measures, about $80 \%$ of area under agriculture belonging to actual productivity class extremely poor to nil could be upgraded to higher categories of potential productivity i.e. excellent $(8.6 \%)$, good $(12.7 \%)$, average $(6.1 \%)$ and poor
(53.1\%). A $63.2 \%$ of area under pastures belonging to actual productivity class extremely poor to nil and poor category could be upgraded to higher categories of potential productivity i.e. excellent $(8.6 \%)$, good $(48.2 \%)$ and average $(6.4 \%)$. A $22.2 \%$ of area under forests/trees belonging to actual productivity class extremely poor to nil could be upgraded to higher categories of potential productivity i.e. average $(7.5 \%)$ and poor (14.7\%). These findings are in line with those of Sharma et al. (2004) for watershed conditions. 
Table 1: Salient characteristics of different mapping units

\begin{tabular}{|c|c|c|c|c|c|c|c|c|c|c|}
\hline $\begin{array}{l}\text { Mapping } \\
\text { Unit }\end{array}$ & $\begin{array}{l}\text { Dominant } \\
\text { Land Use }\end{array}$ & $\begin{array}{l}\text { Slope } \\
\text { class }\end{array}$ & $\begin{array}{c}\text { Soil } \\
\text { erosion }\end{array}$ & $\begin{array}{c}\text { Soil } \\
\text { depth }(\mathrm{cm})\end{array}$ & $\begin{array}{c}\text { Soil } \\
\text { texture }\end{array}$ & \begin{tabular}{|c|} 
Surface \\
Stoniness (\%)
\end{tabular} & $\begin{array}{c}\mathrm{pH} \\
(1: 2) \\
\end{array}$ & $\begin{array}{l}\text { Org. C } \\
\left(\mathrm{g} \mathrm{kg}^{-1}\right)\end{array}$ & $\begin{array}{c}\text { CEC } \\
{\left[\mathrm{cmol}\left(\mathrm{p}^{+}\right) \mathrm{kg}^{-1}\right]}\end{array}$ & BSP \\
\hline \multicolumn{11}{|c|}{ Upper Shiwalik foot hills (>600m, slope mostly >25\%) } \\
\hline $\mathrm{H} 11$ & mixed dense forests & D-I & e2-e3 & 15-33 & gsl - gls & $30-45$ & $6.7-7.0$ & $10.5-10.8$ & 6.8-12.5 & $73.8-76.0$ \\
\hline $\mathrm{H} 12$ & mixed dense forests & C-I & e2-e3 & $18-35$ & gsl - gls & $35-50$ & $6.6-6.8$ & $11.0-12.0$ & 7.8-14.4 & 75.9-78.7 \\
\hline $\mathrm{H} 13$ & Sparse forests & $\mathrm{F}-\mathrm{I}$ & e2-e3 & $21-55$ & gsl-gls & $30-50$ & 6.4-6.6 & 10.8-15.9 & $6.9-12.4$ & 71.7-74.7 \\
\hline \multicolumn{11}{|c|}{ Lower Shiwalik foot hills (500-600m, slope mostly $10-35 \%)$} \\
\hline $\mathrm{H} 21$ & mixed dense forests & A-I & e1-e3 & $22-40$ & gsil - Is & $>40$ & $6.8-6.9$ & $7.6-10.2$ & $13.5-15.4$ & $68.2-75.5$ \\
\hline $\mathrm{H} 22$ & Sparse forests & $\mathrm{F}-\mathrm{H}$ & e3 & $20-40$ & gls & $>40$ & $6.5-6.6$ & $11.0-12.0$ & $6.6-9.5$ & $72.6-77.7$ \\
\hline $\mathrm{H} 23$ & Agriculture & $A-G$ & e1-e3 & $9-105$ & I-gs & $2-20$ & $6.5-7.0$ & $2.7-7.6$ & $7.5-8.8$ & $65.7-82.9$ \\
\hline $\mathrm{H} 24$ & Scrub land & $A-G$ & e1-e3 & $7-35$ & gsil -gls & $>35$ & $6.8-6.9$ & $3.0-7.6$ & $10.3-13.5$ & $66.4-72.6$ \\
\hline $\mathrm{H} 25$ & Grassland & D-H & e1-e3 & $10-75$ & Is - gls & $>40$ & $6.6-6.8$ & $4.8-14.0$ & $6.0-7.9$ & $64.6-75.7$ \\
\hline \multicolumn{11}{|c|}{ Upper piedmonts (450-500m, slope mostly 3-10\%) } \\
\hline P11 & Agriculture & $A-D$ & e1-e3 & $15-110$ & I-gls & $2-15$ & $6.8-7.1$ & $04.5-6.8$ & 4.7-11.3 & $73.5-83.9$ \\
\hline $\mathrm{P} 12$ & Scrub land & $A-I$ & e1-e3 & $18-55$ & Is - gs & 25 & $6.6-6.8$ & $2.7-4.5$ & $7.5-11.2$ & $63.7-74.6$ \\
\hline P13 & Grassland & $A-G$ & e1-e3 & $21-52$ & Is - gs & 40 & $6.2-6.8$ & 4.8-13.9 & $5.8-10.6$ & 69.6-72.6 \\
\hline \multicolumn{11}{|c|}{ Lower piedmonts (450-500m, slope mostly 1-10\%) } \\
\hline P21 & Agriculture & $A-D$ & e1-e3 & $25-120$ & I-gls & $2-13$ & $6.7-7.0$ & $4.6-6.6$ & $8.7-11.3$ & $72.5-83.8$ \\
\hline P22 & Agricultural plantations & $\mathrm{E}$ & e2-e3 & $8-26$ & gls & 25 & $6.8-6.9$ & $3.9-4.4$ & $9.2-11.4$ & 71.5-73.7 \\
\hline P23 & Scrub land & $A-G$ & e1-e3 & $15-76$ & Is - gs & 30 & $6.4-6.8$ & $4.5-14.1$ & 7.2-10.8 & 72.6-77.7 \\
\hline P24 & Grassland & $A-G$ & e1-e3 & $9-74$ & Is - gs & 36 & $6.3-6.8$ & $5.0-13.9$ & 7.7-10.5 & 73.7-76.6 \\
\hline \multicolumn{11}{|c|}{ Flood plains ( $<450 m$, slope mostly $0-5 \%)$} \\
\hline FP1 & Scrub land & B-D & e1-e3 & $19-56$ & gls- gs & 32 & $6.5-6.8$ & $4.8-5.0$ & $7.2-10.1$ & $72.6-75.6$ \\
\hline FP2 & Grassland & $A-D$ & e1-e3 & $23-60$ & Is - gs & 38 & $6.5-6.8$ & $2.7-4.9$ & $5.7-9.5$ & $61.7-78.6$ \\
\hline FP3 & Agriculture & $A-C$ & e1-e3 & $24-100$ & I-gls & $2-10$ & $6.4-7.3$ & 4.7-14.3 & $7.9-11.1$ & $77.6-84.5$ \\
\hline
\end{tabular}



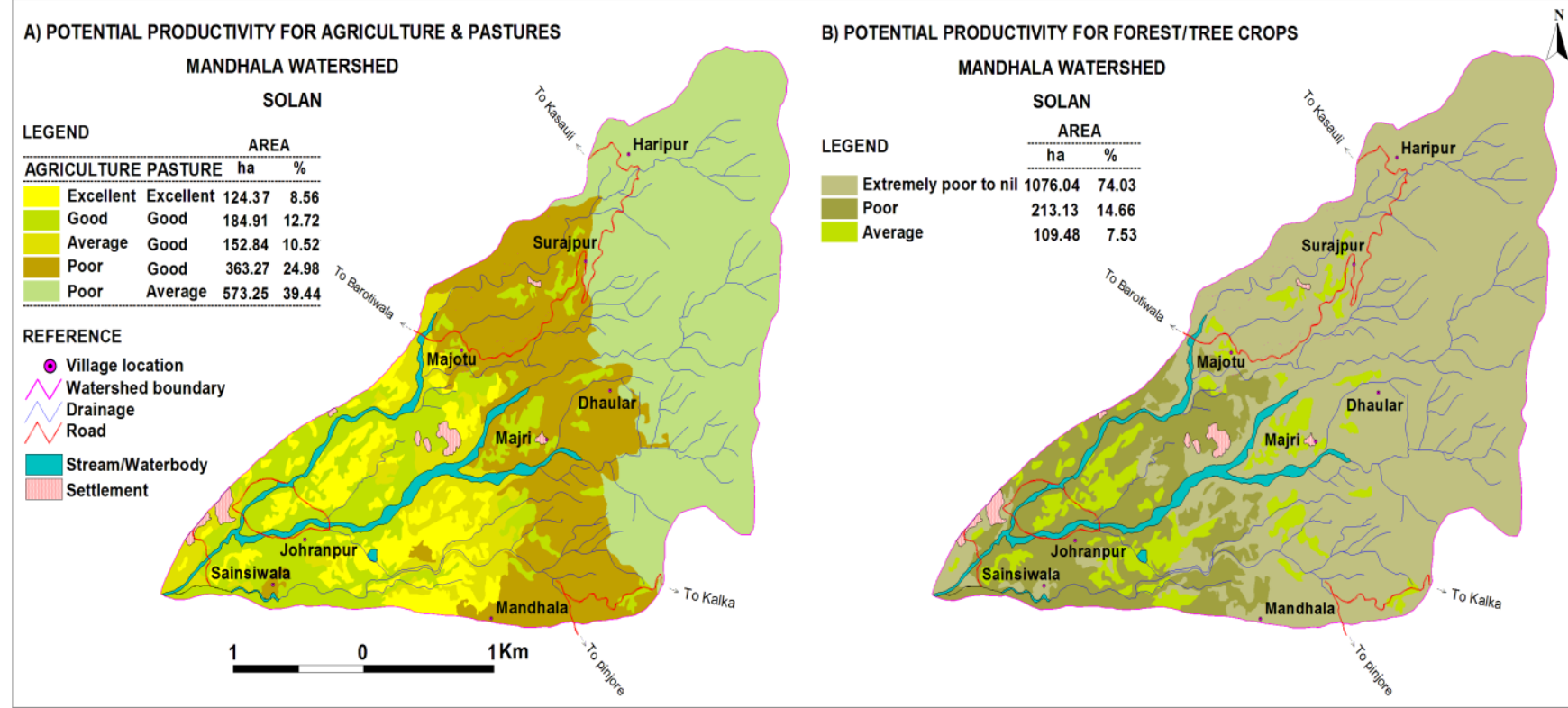

Fig. 2:Potential productivity for different land uses in Mandhala watershed

The productivity of these soils can be raised by increasing effective soil depth (following deep ploughing, breaking of crust, ridging), improving soil structure/texture (by stone/rock removal, mechanical working, organic matter addition), soil organic matter improvement (through application of manures, mulching, following crop rotation), increasing fertility by fertilizer application in suitable quantity, improving soil moisture content (by irrigation where ever possible, mulching), adopting erosion control measures (construction of terraces, drop pits, drains, contour trenches, mulching, hedge grow planting and growing cover crops) especially in sloppy land, improving drainage and protection against floods whenever necessary. Meena et al. (2017) also suggested such conservation measures for improving productivity potential of soils.

\section{Irrigability assessment}

The studied lands were grouped into four irrigability classes (Table 2) based on soil properties like topography, soil depth, surface soil texture, permeability, salinity/alkalinity and drainage characteristics of the area besides considering cost of land development. Irrigability classes identified i.e. 3, 4, 5 and 6 covered an area of $115.71,105.2,380.45$ and 797.29 ha comprising $8.0,7.2,26.2$ and $54.8 \%$ of TGA of the watershed, respectively (Fig. 3). Class 3 lands (P21, P22, FP1, FP2 and FP3 units) have severe limitations of soil like coarse texture, rapid permeability, shallow soil depth and low available water capacity for sustained use under irrigation. The irrigability sub-class is $3 \mathrm{~s}$. They have low productivity potential under irrigated agriculture. Class 4 lands ( $\mathrm{H} 23$ and $\mathrm{P} 13$ units) have very severe limitations of topography and soil which render them marginal for sustained use under irrigation. These have been placed in irrigability sub-class 4 ts and have very low productivity potential under irrigated agriculture except special planning. Class 5 lands $(\mathrm{H} 24$, $\mathrm{H} 25$, P11, P12, P23 and P24 units) are not suitable for irrigation under existing conditions due to very severe limitations of soil and topography. The irrigability sub-class is 5ts. However, after some improvements they are potentially suitable. The irrigation potential of these lands can be increased using drip and sprinkler irrigation, in addition to improvement measures suggested for improving productivity. Similar observations were reported by Mandal et al. (2017) for soils of West Bengal. Class 6 lands $(\mathrm{H} 11, \mathrm{H} 12, \mathrm{H} 13, \mathrm{H} 21$ and $\mathrm{H} 22$ units) belonging to sub-class 6ts are actually and potentially unsuitable for irrigated farming. The adoptive measures for their reclamation are technically and economically non-feasible. 
Table 2:Productivity, potentialily and irrigability classes of studied soils for different land uses

\begin{tabular}{|c|c|c|c|c|c|c|c|c|c|c|c|c|c|c|c|c|}
\hline \multirow{2}{*}{$\begin{array}{c}\text { Mapping } \\
\text { unit }\end{array}$} & \multicolumn{6}{|c|}{ Actual productivity } & \multicolumn{6}{|c|}{ Potential productivity } & \multicolumn{3}{|c|}{ Coefficient of improvement } & \multirow{2}{*}{$\begin{array}{l}\text { Irrigability } \\
\text { class }\end{array}$} \\
\hline & \multicolumn{2}{|c|}{ Agriculture } & \multicolumn{2}{|c|}{ Pastures } & \multicolumn{2}{|c|}{ Forest/trees } & \multicolumn{2}{|c|}{ Agriculture } & \multicolumn{2}{|c|}{ Pastures } & \multicolumn{2}{|c|}{ Forest/trees } & Agriculture & Pastures & \multirow{2}{*}{$\begin{array}{l}\text { Forest } \\
\text { /trees }\end{array}$} & \\
\hline $\mathrm{H} 11$ & $\frac{\text { Index }}{4.16}$ & $\frac{\text { Class }}{5}$ & Index & Class & Index & Class & $\frac{\text { Index }}{760}$ & Class & Index & Class & $\frac{\text { Index }}{1.78}$ & Class & 1.83 & 1.55 & & $6 t s$ \\
\hline $\mathrm{H} 12$ & 4.90 & 5 & 21.26 & 3 & 0.65 & 5 & 7.67 & IV & 28.37 & III & 1.78 & $\mathrm{~V}$ & 1.56 & 1.33 & 2.74 & 6ts \\
\hline $\mathrm{H} 13$ & 4.90 & 5 & 21.26 & 3 & 0.65 & 5 & 7.67 & IV & 28.37 & III & 1.78 & V & 1.56 & 1.33 & 2.74 & 6 ts \\
\hline $\mathrm{H} 21$ & 4.16 & 5 & 18.07 & 4 & 0.55 & 5 & 8.63 & IV & 34.13 & II & 2.96 & V & 2.07 & 1.89 & 5.38 & 6 ts \\
\hline H22 & 4.90 & 5 & 21.26 & 3 & 0.65 & 5 & 8.70 & IV & 34.45 & II & 2.96 & V & 1.78 & 1.62 & 4.55 & 6 ts \\
\hline $\mathrm{H} 23$ & 8.31 & 4 & 12.04 & 4 & 1.98 & 5 & 35.03 & II & 49.08 & II & 23.70 & III & 4.22 & 4.08 & 11.96 & $4 \mathrm{ts}$ \\
\hline H24 & 4.41 & 5 & 19.13 & 4 & 0.58 & 5 & 8.65 & IV & 34.23 & II & 2.96 & V & 1.96 & 1.79 & 5.10 & 5 ts \\
\hline H25 & 4.90 & 5 & 21.26 & 3 & 0.65 & 5 & 8.70 & IV & 34.45 & II & 2.96 & V & 1.78 & 1.62 & 4.55 & 5 ts \\
\hline P11 & 10.53 & 4 & 16.85 & 4 & 1.04 & 5 & 82.05 & I & 82.68 & I & 17.9 & IV & 7.79 & 4.90 & 17.20 & 5 ts \\
\hline P12 & 3.57 & 5 & 12.05 & 4 & 0.28 & 5 & 24.66 & III & 59.52 & II & 4.08 & V & 6.91 & 4.94 & 14.57 & 5 ts \\
\hline P13 & 11.15 & 4 & 17.85 & 4 & 1.1 & 5 & 25.42 & III & 60.10 & ॥ & 4.08 & V & 2.28 & 3.37 & 3.71 & $4 \mathrm{ts}$ \\
\hline P21 & 20.82 & 3 & 30.11 & 3 & 6.61 & 5 & 83.08 & I & 84.01 & I & 25.66 & III & 3.99 & 2.79 & 3.88 & $3 \mathrm{~s}$ \\
\hline P22 & 0.98 & 5 & 5.69 & 5 & 0.52 & 5 & 9.81 & IV & 44.31 & II & 1.60 & V & 10.01 & 7.79 & 3.08 & $3 s$ \\
\hline P23 & 4.92 & 5 & 7.58 & 5 & 0.62 & 5 & 34.69 & II & 37.21 & II & 9.62 & IV & 7.05 & 4.91 & 15.52 & 5 ts \\
\hline P24 & 4.92 & 5 & 7.58 & 5 & 0.62 & 5 & 34.69 & II & 37.21 & II & 9.62 & IV & 7.05 & 4.91 & 15.52 & 5 ts \\
\hline FP1 & 4.37 & 5 & 7.58 & 5 & 0.62 & 5 & 20.69 & III & 37.21 & II & 3.21 & V & 4.73 & 4.91 & 5.18 & $3 s$ \\
\hline FP2 & 4.37 & 5 & 7.58 & 5 & 0.62 & 5 & 34.69 & II & 37.21 & II & 9.62 & IV & 7.94 & 4.91 & 15.52 & $3 s$ \\
\hline FP3 & 20.82 & 3 & 30.11 & 3 & 6.61 & 5 & 83.08 & 1 & 84.01 & I & 25.66 & III & 3.99 & 2.79 & 3.88 & $3 s$ \\
\hline
\end{tabular}

"Productivity class 1 or I = Excellent; 2 or II = Good; 3 or III = Average; 4 or IV = Poor; 5 or V = Extremely poor to nil 


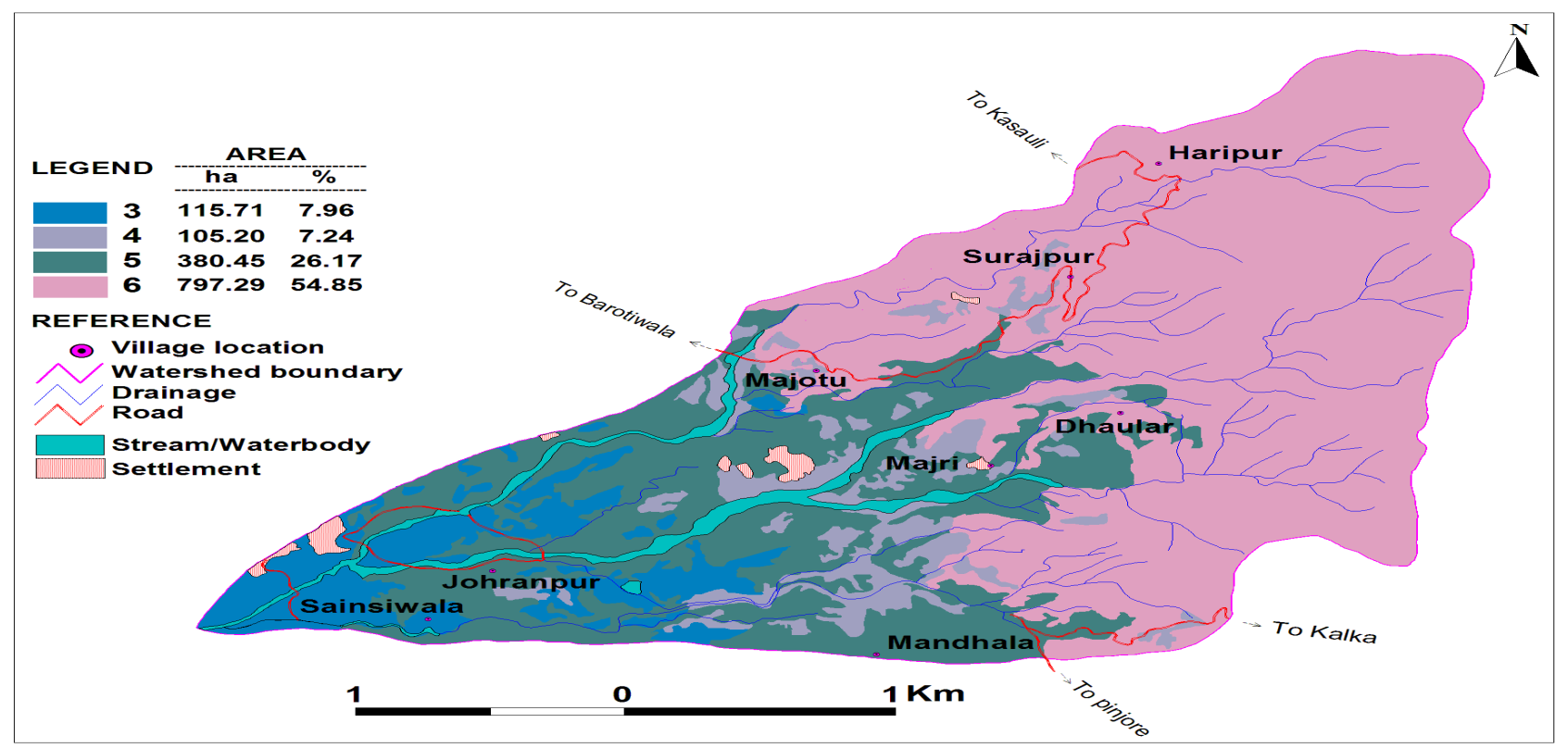

Fig. 3:Land irrigability classification of Mandhala watershed

The study not only showed the relative suitability of the area for agriculture, pastures and forest/trees but it also provided clues for improving the performance of these land uses in order to realize full potential of these lands. Grouping of various mapping units into different land irrigability classes highlighting major constraints will help to ensure efficient and judicious management and utilization of limited water resources particularly during moisture

\section{REFERENCES}

Jackson, M. L. (1973) Soil Chemical Analysis, Prentice Hall of India Private Limited, New Delhi.

Mandal, B., Dolui, G. and Satpathy, S. (2017) Land suitability assessment for potential surface irrigation of river catchment for irrigation development in Kansai watershed, Purulia, West Bengal, India. Sustainable Water Resources Management 4: 699-714.

Meena, G.L., Singh, R.S., Singh, R.K., Meena, H.R, Meena, S. and Mina, B.L. (2017) Assessment of productivity potential of some soils of Aravali hills based on parametric approach. Indian Journal of Soil Conservation 45 (1): 28-39.

Riquier, J., Bramao, D.L. and Cornet, J.P. (1970) A New System of Soil Appraisal in Terms stress period. The results may help in increasing the overall productivity which can ultimately play a pivotal role in the economic development of people living in the watershed.

\section{ACKNOWLEDGEMENT}

Financial support provided by the DST, New Delhi is gratefully acknowledged.

of Actual and Potential Productivity. Soil Resources, Development and Conservation Service, Land and Water Development Division, FAO, Rome, p. 135.

Sarma, V. A. K., Krishnan, P. and Budihal, S. L. (1987)Laboratory Methods, Publ. No. 14, NBSS \& LUP, Nagpur.

Sharma, V.K., Sharma, P.D., Sharma, S.P., Acharya, C.L. and Sood, R.K. (2004) Characterization of cultivated soils of Neogal watershed in North-West Himalayas and their suitability for major crops. Journal of the Indian Society of Soil Science 52: 63-68.

Soil Survey Staff (1951) Soil Survey Manual. USDA Agric.Handb.,18, p. 505. 